\title{
Eutrophication potential of lakes: an integrated analysis of trophic state, morphometry, land occupation, and land use
}

\author{
Silvino, RF. ${ }^{a *}$ and Barbosa, FAR. ${ }^{b}$ \\ ${ }^{a}$ Faculdade de Engenharia e Arquitetura, Universidade Fundação Mineira de Educação e Cultura - FUMEC, \\ Rua Cobre, 200, Cruzeiro, Sala dos professores, CEP 30310-190, Belo Horizonte, MG, Brazil \\ ${ }^{\text {b}}$ Laboratório de Limnologia, Ecotoxicologia e Ecologia Aquática - LIMNE, Instituto de Ciências Biológicas - ICB, \\ Universidade Federal de Minas Gerais - UFMG, Avenida Antônio Carlos, 6627, Pampulha, \\ CEP 30161-970, Belo Horizonte, MG, Brazil \\ *e-mail: renataf@fumec.br
}

Received: October 15, 2013 - Accepted: May 15, 2014 - Distributed: August 31, 2015

(With 2 figures)

\begin{abstract}
Despite being inside a protected area, Lake Sumidouro has been impacted by the anthropogenic occupation of the surrounding area since the 1970's, compromising the ecological integrity of the lake and the sustainable use of natural resources. This study examined the current trophic classification of the lake and developed methods for improving it through an integrated analysis of morphometric and limnological parameters, land use and land occupation in the watershed, and eutrophication potential. Data for the limnological parameters, land use and land occupation, and morphometric characteristics of Lake Sumidouro were collected in the rainy and dry seasons of 2009 and 2010. Depending on the trophic classification system used, Lake Sumidouro is classified as oligotrophic to hypereutrophic. In our study, the highest concentration of nutrients occurred in the rainy season, indicating that high nutrient inputs played an important role during this period. Areas of anthropogenic occupation comprised approximately $62.9 \%$ of the total area of the watershed, with pasture and urban settlement as the main types of land use. The influent total phosphorus load was estimated to be $15,824.3 \mathrm{~kg} / \mathrm{year}$. To maintain mesotrophic conditions, this load must be reduced by $29.4 \%$. By comparing the isolated use of trophic state indices, this study demonstrated that comparing the trophic state classification with morphometric analyses, land use and land occupation types in the watershed, and potential phosphorus load provided better information to guide management actions for restoration and conservation. Furthermore, this approach also allowed for evaluating the vulnerability of the environment to the eutrophication process.
\end{abstract}

Keywords: water quality, trophic indices, phosphorus, restoration, conservation.

\section{Potencial de eutrofização de lagos: uma análise integrada do estado trófico, morfometria, uso e ocupação do solo}

\begin{abstract}
Resumo
A lagoa Sumidouro apesar de incluída em área protegida tem sido impactada pela ocupação antrópica desde os anos 70 , com riscos consideráveis à sua integridade ecológica e utilização sustentável de seus recursos naturais. Este estudo teve como objetivo discutir a classificação trófica comumente utilizada propondo reforça-la através de uma análise integrada dos parâmetros morfométricos e limnológicos, usos e ocupação do solo na bacia e o cálculo do potencial de eutrofização. Parâmetros limnológicos, levantamento dos usos e ocupação do solo e dados morfométricos da lagoa Sumidouro foram medidos nos períodos de chuva e seca de 2009 e 2010 . Dependendo do sistema trófico utilizado a lagoa Sumidouro tem sido classificada desde oligotrófica até hipereutrófica e, no presente estudo apresentou as maiores concentrações de nutrientes durante os períodos de chuvas, demonstrando o papel dos maiores aportes neste período. Do total de sua bacia hidrográfica as áreas antropizadas totalizam c. $62,9 \%$ da área total, sendo que pastagens e ocupação urbana constituem os usos principais. Neste estudo, estimou-se a carga total afluente de fósforo neste ambiente como sendo $15.824,3 \mathrm{kgP} / \mathrm{ano}$. Para manter uma condição de mesotrofia esta carga deverá ser reduzida em $29,4 \%$ deste total. Comparado com o uso isolado de índices de estado trófico, este estudo demonstrou que uma associação da classificação do estado trófico com análises morfométricas, usos e ocupação do solo da bacia e potencial de contribuição de fósforo fornece melhor indicação para ações de gestão visando a recuperação e conservação além de também contemplar, a vulnerabilidade dos ambientes ao processo de eutrofização.
\end{abstract}

Palavras-chave: qualidade da água, índices tróficos, fósforo, recuperação, conservação. 


\section{Introduction}

The trophic state, or stage of eutrophication, of a body of water has been associated with the study and management of cultural eutrophication of lakes. The tropic state concept focuses on variables that are directly or indirectly related to primary productivity (i.e., algae and aquatic plants) (Dodds and Cole, 2007).

Naumann and Thienemann were the first to classify lakes into oligotrophic and eutrophic types in the early part of the twentieth century (Esteves, 1988). Naumann characterized temperate lakes on the basis of their plant production and was in large part concerned with visual or aesthetic symptoms of eutrophication. Thienemann, in contrast, emphasized the degree of hypolimnetic oxygen depletion in summer and the benthic organisms associated with eutrophication (Chapra and Dobson, 1981). This typology has proven to be inapplicable to tropical lakes because these ecosystems show metabolic patterns completely different from temperate lacustrine ecosystems (Esteves, 1988).

Trophic classification systems were initially developed for temperate environments (e.g., Carlson, 1977; OECD, 1982). In an attempt to evaluate eutrophication in tropical areas, several indices that consider the particular characteristics of tropical environments were also developed. For example, the index developed by Toledo et al. (1983), which was constructed similarly to the Carlson's (1977) index, is calculated in a way that gives less weight to the variable "water transparency," which is directly affected by the high turbidity of tropical waters during most of the year. Salas and Martino (1991) proposed a simplified trophic model based on phosphorus levels. More recently, Lamparelli (2004) proposed a modified index based on the Carlson's (1977) index.

According to Dodds and Cole (2007), knowing a lake's trophic state provides basic information that can be used to measure biotic integrity, monitor human influence, and guide restoration planning. Eutrophication is influenced by both anthropogenic and natural factors (Liu et al., 2010). Because of the complex nature of eutrophication, an increasing number of studies are directed toward broader-scale analyses of lakes and reservoirs threatened by this environmental problem. Such analyses involve not only physical and chemical parameters and, trophic state indices but also their relationship with morphology, land use, and land occupation (Nõges et al., 2003; Fraterrigo and Downing, 2008; Taranu and Gregory-Eaves, 2008; Nõges, 2009; Liu et al., 2010). Morphological parameters, such as the depth and volume of the lake, are assumed to be significantly related to nutrient concentrations or eutrophication state (Armengol and Miracle, 1999; Hamilton et al., 2001; Taranu and Gregory-Eaves, 2008; Liu et al., 2010). It is widely accepted that any changes in land use directly impact water quantity and quality (Goonetilleke et al., 2005). Watersheds dominated by agricultural or urbanized land export nutrients to bodies of water at higher rates than undisturbed watersheds. Therefore, land use is directly related to nutrient inputs into bodies of water (Arbuckle and Downing, 2001; Knoll et al., 2003; Sand-Jensen and Staehr, 2007; Taranu and Gregory-Eaves, 2008).

Because of the importance of Lake Sumidouro in the central karstic region of the state of Minas Gerais, Brazil, and specifically its importance to Sumidouro State Park, the lake was selected for use in this study. We examined the trophic classification commonly accepted in the limnological literature using an analysis of the relationships between morphometric and limnological parameters, an evaluation of land use and land occupation in the watershed, and a calculation of the eutrophication potential of the local environment.

We found that an integrated analysis of limnology, trophic state, lake morphometry, watershed use and occupation, and potential influent phosphorus load enabled a more accurate evaluation of environmental quality and the vulnerability of the environment to eutrophication. In addition, the analysis provided information to support the implementation of restoration and conservation measures at Lake Sumidouro.

\section{Material and Methods}

\subsection{Study site}

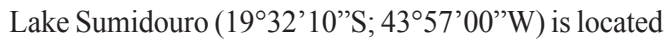
in the central region of the state of Minas Gerais, within the limits of the protected area Sumidouro State Park (Figure 1). The lake is the largest body of water of karstic origin in the region. It is located at an altitude of $650 \mathrm{~m}$ and is bordered to the north by the district of Fidalgo and the municipality of Pedro Leopoldo and to the south by seasonal semideciduous and deciduous forest. Both vegetation types are part of the Atlantic Forest biome.

According to the Köppen classification, the climate in the region is of the type Aw, which includes humid tropical regions with dry winters and rainy summers, mean annual temperatures above $18^{\circ} \mathrm{C}$ in the coldest month, and mean annual precipitation between 1,000 and 1,500 mm (Patrus, 1998).

Despite being part of the Carste de Lagoa Santa Environmentally Protected Area, the Sumidouro Lake watershed experienced considerable long-term impacts resulting from changes in the matrix of land occupation. Furthermore, inadequate sanitation infrastructure in the region has impacted the lake environment and, due to the high vulnerability of karstic regions to environmental degradation, makes restoration of the lake very complex.

\subsection{Limnological data and trophic level}

Limnological parameters were measured in the rainy and dry seasons of 2009 and 2010 at two sampling locations (limnetic and littoral zones). Sampling was performed in February and September of 2009 and March and July of 2010. Dissolved oxygen, $\mathrm{pH}$. and water transparency were measured in situ. Water samples were collected at the subsurface level $(0.5 \mathrm{~m})$ for analyses of chlorophyll- $a$, total phosphorus $(\mathrm{P})$, soluble reactive phosphorus $\left(\mathrm{PO}_{4}-\mathrm{P}\right)$, total 


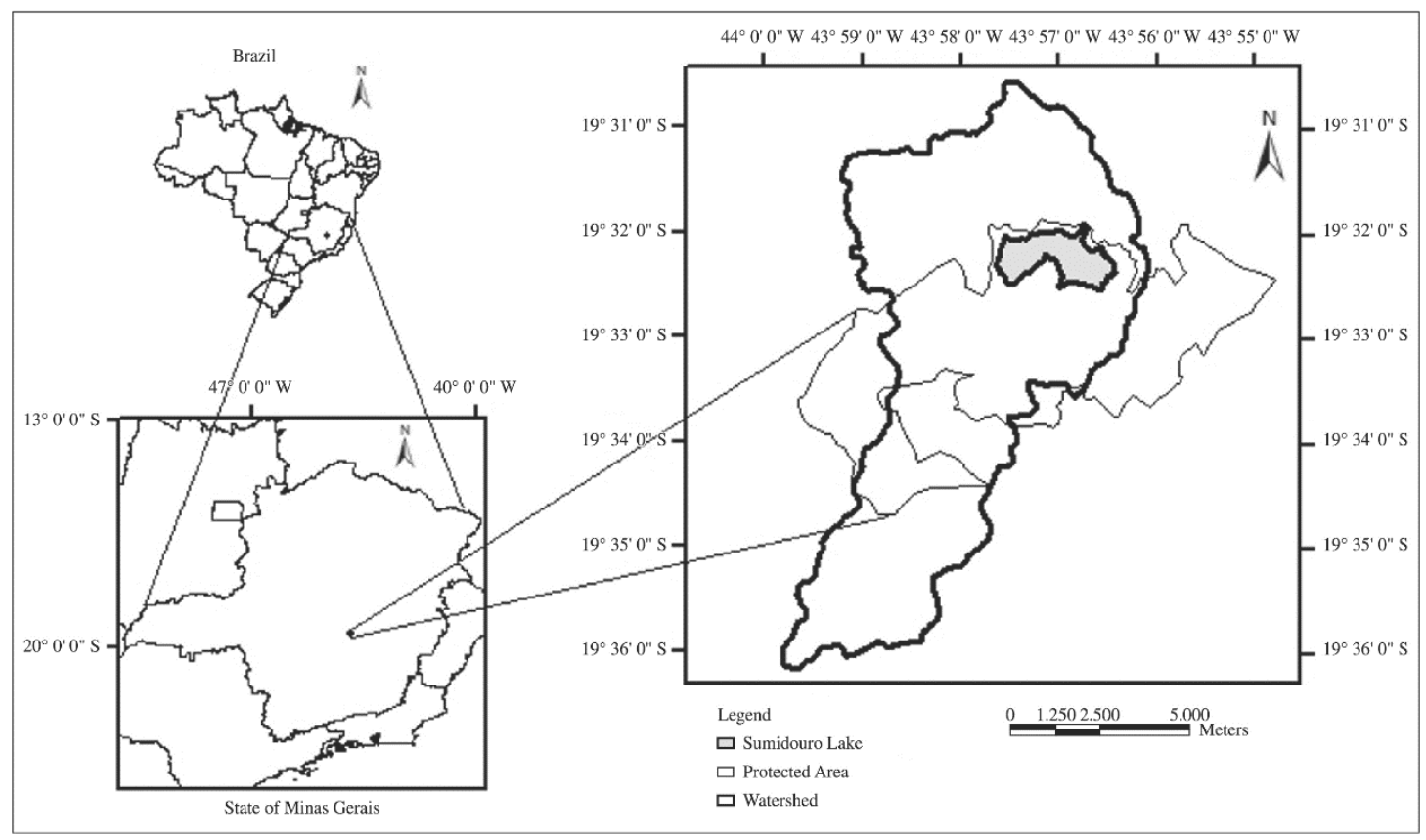

Figure 1. Location of Lake Sumidouro (Minas Gerais, Brazil). Note the boundaries of the watershed and the protected area Sumidouro State Park.

nitrogen $(\mathrm{N})$, nitrate $\left(\mathrm{NO}_{3}^{-}\right)$, nitrite $\left(\mathrm{NO}_{2}^{-}\right)$, and ammonium $\left(\mathrm{NH}_{4}^{+}\right)$and analyzed according to Lorenzen (1967), Koroleff (1976), Golterman et al. (1978), and Mackeret et al. (1978). Trophic level was evaluated by analyzing the limits of the trophic classification of temperate environments developed by Carlson (1977) and that of the OECD (1982). Indices that take into account the particularities of tropical environments were also considered, including Carlson (1977) modified by Toledo et al. (1983), Salas and Martino (1991), and Carlson (1977) modified by Lamparelli (2004).

\subsection{Bathymetry and morphometric parameters of Lake Sumidouro}

For the morphometric characterization of Lake Sumidouro, a bathymetric survey was performed in April 2011 using a Hummingbird Piranha-2XM probe. Depth measurements were obtained from 21 parallel transects that were perpendicular to the longer axis (length) of the lake. Using the bathymetric data, the following primary and secondary morphometric parameters were obtained: maximum depth, total volume, lake area, surface contribution area, maximum length, and maximum width. Values for these parameters were obtained from measurements performed with the ArcGIS $9.3^{\circledR}$ software (ESRI Inc.) using images from the Landsat 5 satellite. The secondary parameters mean depth, relative depth, perimeter development, and volume development were calculated according to Wetzel (2001). The bathymetric maps were elaborated using a historic series of Landsat 5 satellite images provided by the Brazilian National Institute of Spatial Research (Instituto Nacional de Pesquisas Espaciais (INPE)) and depth data collected in the dry and rainy seasons of 2009 and 2010.
Values for the primary and secondary morphometric parameters were determined for each of these four periods.

\subsection{Watershed land use and land occupation}

For the survey of the land use and occupation, a visual and/or digital interpretation of satellite images was performed, followed by field visits to ground-truth our interpretations. The methodological sequence consisted of the following steps: image selection, assembly of color composites and a cartographic base, georeferencing of images with the aid of the cartographic base, digital processing of images, interpretation and quantification of land use classes, and qualitative analysis of the results.

\subsection{Estimating maximum phosphorus load}

The calculations for estimating maximum phosphorus load accounted for variation in phosphorus concentrations released into the water by different types of land use. Mean values for phosphorus per unit area and existing human population were determined for each type of land use. Phosphorus concentrations were based on population estimates from the Brazilian Institute of Geography and Statistics (Instituto Brasileiro de Geografia e Estatística (IBGE), 2010) and theoretical estimates of external phosphorus loads proposed by Salas and Martino (1991).

Estimates for the influent phosphorus load to the lake from raw domestic sewage were obtained using a contribution rate of $1 \mathrm{~kg}$ P/inhabitant/year (Salas and Martino, 1991). For the load resulting from cattle operations, the following factors were considered: area of pasture currently in use in the watershed, mean carrying capacity of pastures in the region $\left(1.5\right.$ cattle $\left./ 0.01 \mathrm{~km}^{2}\right)$ (IMA, 2011), and a 
contribution rate of $7 \mathrm{~kg} \mathrm{P} /$ animal/year, according to OPS (2001). Estimates of phosphorus concentrations in the lake and the acceptable influent load were obtained according to Salas and Martino (1991), respectively, in the following manner (Equations 1 and 2):

$$
\begin{gathered}
P=\frac{L \cdot 10^{3}}{V \cdot\left(\frac{1}{t}+\frac{2}{\sqrt{t}}\right)} \\
L=\frac{P \cdot V\left(\frac{1}{t}+\frac{2}{\sqrt{t}}\right)}{10^{3}}
\end{gathered}
$$

Where:

$P=$ Predicted median annual in-lake total phosphorus (TP) concentration $\left(\mathrm{gP} / \mathrm{m}^{3}\right)$;

$L=$ Areal total phosphorous load ( $\mathrm{kgP} /$ year);

$V=$ Lake water volume $\left(\mathrm{m}^{3}\right)$;

$t=$ Hydraulic retention time (year).

The value of $0.025 \mathrm{mg} / \mathrm{L}$ of phosphorus was used as the threshold for determining eutrophy (Vollenweider, 1968) (Equation 2). This value was also used as the quality standard for total phosphorus concentration for freshwater bodies categorized as Class 1 in the Brazilian federal legislation for the classification of freshwater (Brasil, 2005) case of Lake Sumidouro.

\subsection{Statistical analyses}

Analyses were performed with R 2.11.0 software. Table 1 summarizes the statistical data for the limnological and morphologic parameters of Lake Sumidouro. There were significant differences among year, season and sampling location (limnetic or littoral zone) for the limnological parameters and significant differences between year and season for the morphological parameters. A Shapiro-Wilk test was used to verify the normality of the data distribution. Student's t-tests were used for variables with a normal distribution and Mann-Whitney tests were used for variables that did not show a normal distribution. The relationships between morphological and limnological parameters were obtained with a Spearman's test. A principal components analysis (PCA) was performed, and the relationship between the two sets of variables (morphological and limnological parameters) and season of the year was tested using Spearman's tests.

\section{Results}

\subsection{Trophic state of Lake Sumidouro}

Because trophic classifications are completed on an annual basis, the mean values for the dry and rainy seasons in 2009 and 2010 were analyzed. The eutrophic class was the predominate class according to both the Carlson's (1977) index and the system proposed by the OECD (1982). According to both systems, Lake Sumidouro was

Table 1. Summary of the descriptive analysis of limnological and morphological parameters of Lake Sumidouro in 2009

\begin{tabular}{|c|c|c|c|c|c|}
\hline & $\mathbf{N}$ & Mean & $\begin{array}{l}\text { Standard } \\
\text { deviation }\end{array}$ & $\begin{array}{c}\begin{array}{c}\text { Minimum } \\
\text { value }\end{array} \\
\end{array}$ & $\begin{array}{c}\text { Maximum } \\
\text { Value }\end{array}$ \\
\hline \multicolumn{6}{|l|}{ Limnological parameter } \\
\hline Ammonia $\left(\mu \mathrm{g} 1^{-1}\right)$ & 8 & 60.79 & 47.10 & 10.21 & 139.88 \\
\hline Nitrite $\left(\mu g 1^{-1}\right)$ & 8 & 0.68 & 0.77 & 0.00 & 2.08 \\
\hline Nitrate $\left(\mu \mathrm{g} \mathrm{1^{-1 } )}\right.$ & 8 & 9.17 & 7.50 & 0.29 & 19.53 \\
\hline Total nitrogen $\left(\mu \mathrm{g} 1^{-1}\right)$ & 8 & 338.94 & 171.55 & 147.48 & 612.38 \\
\hline Orthophosphate $\left(\mu \mathrm{g} \mathrm{1^{-1 } )}\right.$ & 8 & 1.65 & 1.06 & 0.36 & 2.82 \\
\hline Total phosphorus $\left(\mu \mathrm{g} 1^{-1}\right)$ & 8 & 46.08 & 25.14 & 26.38 & 85.41 \\
\hline Chlorophyll $a\left(\mu \mathrm{g} \mathrm{1^{-1 } )}\right.$ & 8 & 10.03 & 5.61 & 1.60 & 17.74 \\
\hline Dissolved oxygen $\left(\mathrm{mg} \mathrm{1}^{-1}\right)$ & 8 & 7.70 & 2.05 & 4.15 & 9.00 \\
\hline $\mathrm{pH}$ & 8 & 7.45 & 0.18 & 7.14 & 7.74 \\
\hline Transparency (Secchi disk) (m) & 8 & 0.75 & 0.58 & 0.25 & 1.75 \\
\hline \multicolumn{6}{|l|}{ Morphometric parameters } \\
\hline Maximum depth (m) & 8 & 3.55 & 0.91 & 2.70 & 4.40 \\
\hline Mean depth (m) & 8 & 0.71 & 0.37 & 0.36 & 1.10 \\
\hline Volume $\left(10^{4} \mathrm{~m}^{3}\right)$ & 8 & 57.23 & 45.24 & 14.76 & 99.86 \\
\hline Area $\left(\mathrm{Km}^{2}\right)$ & 8 & 0.68 & 0.30 & 0.39 & 1.04 \\
\hline Relative depth (\%) & 8 & 0.39 & 0.02 & 0.36 & 0.42 \\
\hline Maximum length (m) & 8 & $1,545.00$ & 403.79 & $1,164.00$ & $1,964.00$ \\
\hline Maximum width (m) & 8 & 694.75 & 189.85 & 511.00 & 927.00 \\
\hline Perimeter $(\mathrm{km})$ & 8 & 4.90 & 0.97 & 3.95 & 6.02 \\
\hline Volume development & 8 & 0.56 & 0.17 & 0.40 & 0.75 \\
\hline Perimeter development & 8 & 1.72 & 0.05 & 1.67 & 1.78 \\
\hline
\end{tabular}
and 2010 . 
considered mesotrophic in 2010, chlorophyll $a$ was used as the evaluation parameter. According to the OECD (1982) system, the lake was considered hypereutrophic when including the Secchi disk values (Table 2).

The indices proposed for tropical environments (Carlson (1977) modified by Toledo et al., 1983; Salas and Martino, 1991; and Carlson (1977) modified by Lamparelli, 2004) showed discrepant results for the trophic state of Lake Sumidouro, with the tropic state varying from oligotrophic to hypereutrophic as shown in Table 2.

\subsection{Limnological and morphological data for Lake Sumidouro}

There were no differences in the limnological parameters between the dry and rainy season $(\mathrm{p} \geq 0.05)$. However, the mean values for nutrients and chlorophyll $a$ were higher in the rainy season. In the rainy season, total nitrogen, total phosphorus, orthophosphate, and chlorophyll $a$ had mean concentrations of $345.38 \mu \mathrm{g} 1^{-1}, 55.65 \mu \mathrm{g} 1^{-1}$, $2.10 \mu \mathrm{g} 1^{-1}$, and $13.12 \mu \mathrm{g} 1^{-1}$, respectively, in the dry season and $332.49 \mu \mathrm{g} 1^{-1}, 36.51 \mu \mathrm{g} 1^{-1}, 1.20 \mu \mathrm{g} 1^{-1}$, and $6.95 \mu \mathrm{g} 1^{-1}$, respectively, in the rainy season. There were no significant differences in the limnological parameters between sampling locations (limnetic and littoral zones) or years (2009 and 2010) ( $\mathrm{p} \geq 0.05)$, except for nitrite, which showed a higher mean concentration in 2010 than in $2009(\mathrm{p}<0.05)$.

Resolution Number 357 of the Brazilian National Environmental Council (Conselho Nacional de Meio Ambiente (CONAMA)) established water quality standards for Brazilian freshwater bodies (Brasil, 2005). Lake Sumidouro showed mean concentrations of total phosphorus that were higher than the limit established for Class 1 water bodies in both the rainy $\left(55.65 \mu \mathrm{g}^{-1}\right)$ and dry (36.51 $\left.\mu \mathrm{g}^{-1}\right)$ season. Additionally, during the rainy season, chlorophyll $a$ was higher than the limit of $10 \mu \mathrm{g} / \mathrm{L}^{-1}$ established for Class 1 waters.

There were no significant differences in the morphological variables between years $(p \geq 0.05)$. However, there were significant differences between seasons $(p<0.05)$, with higher means occurring in the rainy season. Mean values for morphological variables in the dry and rainy seasons were 2.70 and $4.40 \mathrm{~m}$, respectively, for mean depth; 14.91 and $99.5510^{4} \mathrm{~m}^{3}$, respectively, for volume; and 0.96 and $0.41 \mathrm{~km}^{2}$, respectively, for area. Perimeter development was the only variable that showed a higher value in the dry season, when surface contours on the lake were more irregular. Perimeter development had mean values of 1.68 in the rainy season and 1.77 in the dry season. Large seasonal variation in morphological characteristics is typical of karstic aquatic ecosystems because they depend on the rainfall regimes, which are associated with the water table and the flow systems of the karstic aquifers.

Table 3 shows the correlations between the limnological and morphological variables by the Spearman's test. Correlation coefficients greater than 0.70 were considered significant $(\mathrm{p} \leq 0.05)$. The results indicated that chlorophyll $a$ increased with mean depth, relative depth, and the index of volume development. Maximum depth was positively correlated with water transparency, which favored phytoplanktonic biomass (chlorophyll $a$ concentrations).

Table 2. Trophic state classification for Lake Sumidouro according to Carlson (1977); OECD (1982); Carlson (1977) modified by Toledo et al. (1983); Salas and Martino (1991); and Carlson (1977) modified by Lamparelli (2004), based on mean values for the dry and rainy seasons in 2009 and 2010.

\begin{tabular}{|c|c|c|c|}
\hline Trophic Model/Index & Year & Value & $\begin{array}{c}\text { Trophic } \\
\text { Classification }\end{array}$ \\
\hline \multirow[t]{2}{*}{ Carlson (1977) TP $\left(\mu \mathrm{g} \mathrm{1^{-1 } )}\right.$} & 2009 & 59.55 & Eutrophic \\
\hline & 2010 & 59.32 & Eutrophic \\
\hline \multirow{2}{*}{ Carlson (1977) Chlorophyll $a\left(\mu \mathrm{g} 1^{-1}\right)$} & 2009 & 56.57 & Eutrophic \\
\hline & 2010 & 46.76 & Mesotrophic \\
\hline \multirow[t]{2}{*}{ Carlson (1977) Secchi (m) } & 2009 & 59.29 & Eutrophic \\
\hline & 2010 & 58.36 & Eutrophic \\
\hline \multirow[t]{2}{*}{ OECD (1982) TP $\left(\mu \mathrm{g} 1^{-1}\right)$} & 2009 & 60.78 & Eutrophic \\
\hline & 2010 & 39.64 & Eutrophic \\
\hline \multirow[t]{2}{*}{ OECD (1982) Chlorophyll $a\left(\mu g 1^{-1}\right)$} & 2009 & 14.16 & Eutrophic \\
\hline & 2010 & 5.21 & Mesotrophic \\
\hline \multirow[t]{2}{*}{ OECD (1982) Secchi (m) } & 2009 & 1.05 & Hypereutrophic \\
\hline & 2010 & 1.12 & Hypereutrophic \\
\hline \multirow[t]{2}{*}{ TSI Carlson (1977) modified by Toledo et al. (1983) } & 2009 & 42.24 & Oligotrophic \\
\hline & 2010 & 43.70 & Oligotrophic \\
\hline \multirow[t]{2}{*}{ Salas and Martino (1991) TP ( $\mu \mathrm{g} \mathrm{1^{-1 } )}$} & 2009 & 60.78 & Mesotrophic \\
\hline & 2010 & 39.64 & Mesotrophic \\
\hline \multirow[t]{2}{*}{ TSI Carlson (1977) modified by Lamparelli (2004) } & 2009 & 65.49 & Supereutrophic \\
\hline & 2010 & 61.74 & Eutrophic \\
\hline
\end{tabular}


In contrast, the concentration of dissolved oxygen was negatively correlated with volume, area, maximum length, perimeter, and perimeter development.

Major trends in the 10 limnological variables were evaluated using a PCA, in which the first two principle components explained $60 \%$ of the total variability in the data. The sampling units were separated according to the seasonality (Figure 2a). Higher values of nitrate and dissolved oxygen were grouped with dry season, whereas

Table 3. Correlation matrix between the limnological and morphological variables according to the Spearman's test. Significant correlations are indicated in bold text.

\begin{tabular}{cccc}
\hline Variables & $\begin{array}{c}\text { Chlorophyll } \\
\boldsymbol{a}\end{array}$ & $\begin{array}{c}\text { Dissolved } \\
\text { Oxygen }\end{array}$ & Secchi \\
\hline $\begin{array}{c}\text { Maximum } \\
\text { depth }\end{array}$ & 0.655 & -0.671 & $\mathbf{0 . 6 9 7}$ \\
$\begin{array}{c}\text { (Zmax) } \\
\text { Mean depth } \\
\text { (Zmean) }\end{array}$ & $\mathbf{0 . 7 8 1}$ & -0.350 & 0.572 \\
$\begin{array}{c}\text { Volume (V) } \\
\text { Area (A) }\end{array}$ & 0.390 & $\mathbf{- 0 . 8 5 0}$ & 0.676 \\
$\begin{array}{c}\text { Relative } \\
\text { depth (Zrel) }\end{array}$ & $\mathbf{0 . 7 7 2}$ & -0.079 & 0.411 \\
$\begin{array}{c}\text { Maximum } \\
\text { length (L) }\end{array}$ & 0.390 & $\mathbf{- 0 . 8 5 0}$ & 0.676 \\
$\begin{array}{c}\text { Maximum } \\
\text { width (W) }\end{array}$ & 0.488 & -0.650 & 0.624 \\
$\begin{array}{c}\text { Perimeter } \\
\text { (P) }\end{array}$ & 0.390 & $\mathbf{- 0 . 8 5 0}$ & 0.676 \\
$\begin{array}{c}\text { Volume } \\
\text { development } \\
\text { (Dv) }\end{array}$ & $\mathbf{0 . 7 8 1}$ & -0.350 & 0.572 \\
$\begin{array}{c}\text { Perimeter } \\
\text { development } \\
\text { (Dp) }\end{array}$ & -0.390 & $\mathbf{0 . 8 5 0}$ & -0.676 \\
\hline
\end{tabular}

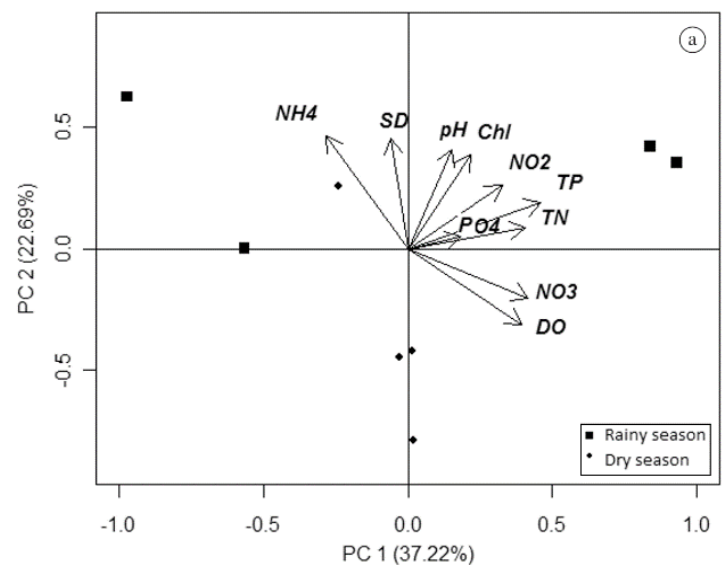

higher values of chlorophyll $a, \mathrm{pH}$, water transparency, and ammonia were grouped with rainy season.

The separation between sampling units was a function of the response of the morphological variables to seasonality. For the morphological data, $92.8 \%$ of the total variation was explained in the first principal component (Figure 2b). Rainy season was associated with higher values of the morphometric variables (maximum depth, mean depth, volume, area, relative depth, maximum length, perimeter, and index of volume development), higher nutrient, $\mathrm{pH}$, and water transparency levels were detected when the lake had a higher volume, area, and mean depth.

\subsection{Land use and land occupation in the watershed and estimates of maximum phosphorus load}

Lake Sumidouro represented approximately 32.3\% of the area of the watershed, which was comprised of seasonal forest cover, cerrado remnants, and $4.78 \%$ bodies of water. The remaining area $(62.92 \%)$ included the following uses: pasture/field (55.01\%), rural/urban area $(6.66 \%)$, agricultural areas $(0.62 \%)$, mining $(0.4 \%)$. and pisciculture $(0.23 \%)$. The watershed overlaps two districts: the district of Fidalgo, belonging to the municipality of Pedro Leopoldo, with 2,595 inhabitants; and the district of Lapinha, belonging to the municipality of Lagoa Santa, with 3,921 inhabitants (IBGE, 2010). Therefore, a total of 6,516 inhabitants contributed to the phosphorus load through sewage, which is disposed of in natura in bodies of water or septic tanks in the region (COPASA, 2009). The number of head of cattle was $1,282.5$, based on a total pasture area in the watershed of $8.55 \mathrm{~km}^{2}$ and a mean carrying capacity for the region of 1.5 head of cattle per $0.01 \mathrm{~km}^{2}$ (IMA, 2011). The phosphorus loads from runoff from forested areas (104.8 $\mathrm{kgP} /$ year), agricultural use (10 kgP/year), and urban use (216 kgP/year), in addition to the loads produced by human and cattle populations, comprised a total load of $15,824.3 \mathrm{kgP} /$ year.

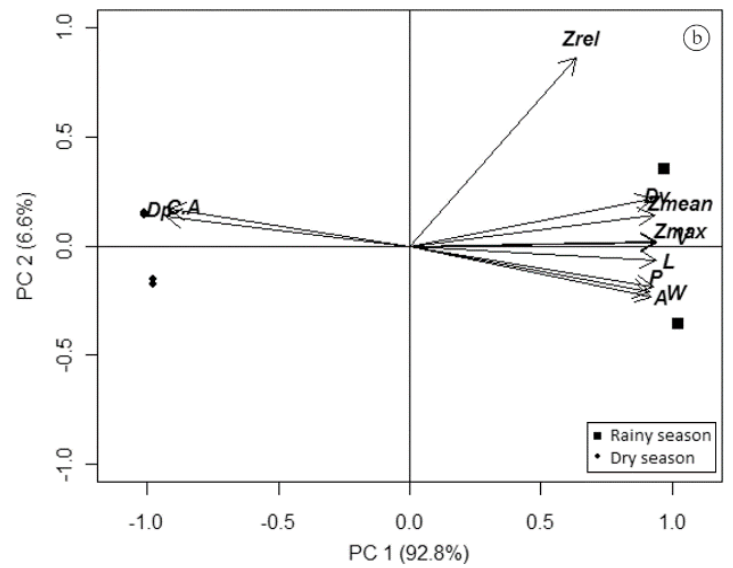

Figure 2. Ordination of sampling units by Principal Components Analysis (Axes 1 and 2) as a function of limnological (a) and morphometric (b) variables measured in Lake Sumidouro in the rainy and dry season in 2009 and 2010. DO: dissolved oxygen; SD: Secchi disk; Chl: chlorophyll a; TP: total phosphorus; PO4: soluble reactive phosphorus; NO3: nitrate, NO2: nitrite; and NH4: ammonia. Abbreviations of morphometric parameters follow those in Table 3. 
The period of water retention, which was obtained using the ratio of volume $\left(57.2310^{4} \mathrm{~m}^{3}\right)$ to influent flow rate $\left(0.517 \mathrm{~m}^{3} / \mathrm{s}\right)$ was 12.8 days, and the estimated value of phosphorus concentrations in the lake was $0.035 \mathrm{mg} / \mathrm{L}$, which is typical of a mesotrophic environment according to OPS (2001). To maintain this trophic condition, the influent load must be reduced from $15,824.3 \mathrm{kgP} /$ year to $11,173.29 \mathrm{kgP} /$ year (a reduction of $29.4 \%$ ), assuming a maximum phosphorus concentration of $0.025 \mathrm{mg} / \mathrm{L}$.

\section{Discussion}

Lake Sumidouro was classified at different trophic levels depending on the trophic classification system used. For the Carlson's (1977) index and the classification system proposed by the OECD (1982), the differences were most likely due to these two classification systems being developed for temperate environments. Thus, the systems were not necessarily applicable in tropical and subtropical environments, which typically have a higher tolerance for high phosphorus and algal biomass levels. Kitaka et al. (2002) have suggested phosphorus concentrations of 50 to $60 \mu \mathrm{g} \mathrm{L}^{-1}$ for meso-eutrophic environments, which was true for Lake Sumidouro during the rainy season. These values are higher than those established for temperate environments in the same category. Similarly, the model proposed by the OECD (1982) considers an eutrophic environment to have a phosphorus concentration of $\geq 35 \mu \mathrm{gL}^{-1}$, which is much lower than the limits proposed for the same trophic classification for tropical systems.

The use of different parameters (e.g., total phosphorus, chlorophyll $a$, and water transparency) contributed to the inconsistency among the classification systems. In this study, Lake Sumidouro was classified as mesotrophic according to the Salas and Martino's (1991) index, which uses total phosphorus concentrations as the central indicator of quality. However, the lake was classified as eutrophic to supereutrophic according to the Carlson's index modified by Lamparelli (2004), which uses data for chlorophyll $a$ concentrations in addition to total phosphorus. Similarly, Lamparelli's (2004) index uses a set of parameters that tends to result in bodies of water being classified at a higher trophic level. According to the author, this allows for distinguishing between environments with high concentrations of chlorophyll $a$ and total phosphorus. These findings stress the fact that there is not necessarily correspondence among existing models for trophic categories, which limits the widespread use of such classification systems. Mercante and Tucci-Moura (1999) recommend the cautious use of such indices as the only indicator of the potential of a trophic state. According to these authors, the temporal and spatial dynamics of the physical, chemical, and biological variables in the aquatic system must be considered, along with the regional particularities of the watershed.

The morphometric variables and analyses of land use and land occupation in the watershed were considered in the environmental evaluation, mainly in reference to their role in cultural eutrophication. The size of the lake and the watershed, for example, are important aspects because they affect nutrient flow, not only from superficial runoff and input from subterraneous waters but also from the re-suspension of sediments induced by the wind (Nõges, 2009; Liu et al., 2010; Sheela et al., 2011). Lake Sumidouro showed higher nutrient concentrations and higher values for the morphometric variables in the rainy season, most likely due to higher loads originating from the watershed. Therefore, the dilution factor was not a determinant for the decrease in nutrient concentrations during this period. Chlorophyll $a$ followed a similar trend, showing a positive correlation with mean depth, which increases water transparency. This pattern was also detected by Liu et al. (2010).

Nutrient concentrations decreased in the dry season, most likely because of the decrease in nutrient inputs from the watershed and because of the assimilation of the nutrients by the macrophyte community, which grows rapidly during that time of year. This result is corroborated by the higher values for perimeter development during the dry season. Variation in the shore of the water body enables the development of a more extensive littoral vegetation. Therefore, during the dry season, even with a higher involvement value (ratio of the area of the lake the area of the watershed), there was a decrease in nutrient concentrations and an increase in dissolved oxygen concentrations.

Changes in land use and vegetation cover are driven by complex interactions among environmental and socio-economic factors (Hietel et al., 2004). Coutinho and Barbosa (1986) stressed the importance of anthropogenic impacts and the necessity of regulating the use of water from karst lakes and activities in their watersheds. Lake Sumidouro is a priority for restoration and conservation actions in this region, not only because it is located in a fully protected conservation unit (Sumidouro State Park) but also because of the high vulnerability of karstic drainages to environmental degradation.

Catchment export nutrients to aquatic ecosystems are influenced by land use practices, for example, watersheds dominated by agriculture, typically export nutrients at higher rates (Knoll et al., 2003; Taranu and Gregory-Eaves, 2008; Vanni et al., 2011). Pasture was the main type of land use in the watershed and thus the main source of nutrients. Part of the pasture area was incorporated into Sumidouro State Park. Although these areas are likely to be converted to natural vegetation by processes of regeneration or replanting, they are commonly invaded by bovines and equines, showing the lack of protection of the area. Manure production causes a P surplus to accumulate in soil, some of which is transported to aquatic ecosystems (Carpenter et al. 1998). Furthermore, the nutrient inputs from urban areas to this lake are significant and mainly reach the lake via the Samambaia river, the lake's main tributary, which drains the districts of Fidalgo and Lapinha. These districts lack 
any type of sewage treatment (COPASA, 2009). As a result, Lake Sumidouro is prone to eutrophication. Despite its short retention period (12.8 days, which favors water renewal, the lake receives a significant phosphorus inputs that are constantly present in the water column due to the re-suspension of sediments that results from the shallow depth of the lake.

Of the indices for tropical environments examined here, the Carlson's (1977) index modified by Toledo et al. (1983) was not adequate. This index underestimated the trophic state of the lake (classified as oligotrophic) despite the use of additional variables, most notably, water transparency. However, water transparency is particularly critical in tropical waters, which are usually turbid during rainy periods. Alternatively, the indices developed by Salas and Martino (1991) and Carlson (1977) modified by Lamparelli (2004) seemed more appropriate for the lakes in this region because they did not underestimate the trophic state and took phosphorus concentrations into account. Phosphorus is an element that acts as limiting factor for primary production and whose availability is fundamental for the definition of the trophic level in aquatic ecosystems.

Given the large variation observed among the results of the indices evaluated in this study, we concluded that the isolated use of a single trophic state index should be performed with caution because the index may not represent the true environmental conditions in a given area. Furthermore, our results suggest that, regardless of which index is used, it should be integrated into an analysis with other environmental quality indicators for the study area. Morphometric analyses and the evaluation of land use and land occupation in the watershed are particularly important. Anthropogenic impacts such as point and nonpoint source pollution are the main determinants of lake eutrophication, Liu et al. (2010) noted that some natural factors, such as lake morphology that reflect lake buffer capacity to nutrient inputs can also play important roles in explaining the eutrophication status.

Lake Sumidouro must meet the classification of Class 1 waters, which is designed for example for the protection of aquatic communities and the supply for human consumption after treatment simplified. Currently, this lake shows limnological characteristics, including total phosphorus and chlorophyll $a$, that are above the limits established for this class. This result indicates the need for urgent actions regarding the regulation of land use in the watershed, such as limiting or prohibiting activities that are incompatible with ecosystem health and the health of the local population. Examples of urgently needed actions include the collection, treatment, and disposal of the sanitary sewage that is currently released into this environment. This action would directly reduce phosphorus inputs. Furthermore, according to Schindler (2012), it is the only method that has had proven success in reducing eutrophication in lakes. Slowing and halting the process of eutrophication is essential for maintaining the mesotrophic state of Lake Sumidouro.

\section{Acknowledgments}

The authors thank professors Marcelo de Ávila Chaves and Pedro Fialho Cordeiro for their support in the morphometric analysis and the land use and occupation analyses; Jôse Lorena Guimarães da Silva and Thiago Bressani Ribeiro for field and laboratory assistance; and the State Forest Institute (Instituto Estadual de Florestas), especially the manager of the Sumidouro State Park, Rogério Tavares de Oliveira, for their logistical support.

\section{References}

ARBUCKLE, KE. and DOWNING, JA., 2001. The influence of watershed land use on lake N:P in a predominantly agricultural landscape. Limnology and Oceanography, vol. 46, no. 4, p. 970975. http://dx.doi.org/10.4319/1o.2001.46.4.0970.

ARMENGOL, X. and MIRACLE, MR., 1999. Zooplankton communities in doline lakes and pools, in relation to some bathymetric parameters and physical and chemical variables. Journal of Plankton Research, vol. 21, no. 12, p. 2245-2261. http://dx.doi.org/10.1093/plankt/21.12.2245

Brasil. Conselho Nacional do Meio Ambiente - CONAMA, 2005. Resolução no. 357, de 17 de março de 2005. Dispõe sobre a classificação dos corpos de água e diretrizes ambientais para $o$ seu enquadramento, bem como estabelece as condições $e$ padrões de lançamento de efluentes, e dá outras providências. Diário oficial da União, Brasília, 18 mar. Secção1, no. 53, p. 58-63. Available from: <http://www.mma.gov.br/port/conama/ res/res05/res.35705.pdf>. Access in: Acesso em: 20 Oct. 2009.

CARLSON, RE., 1977. A trophic state índex for lakes. Limnology and Oceanography, vol. 22, no. 2, p. 361-369. http://dx.doi. org/10.4319/lo.1977.22.2.0361

CARPENTER, SR., CARACO, NF., CORRELL, DL., HOWARTH, RW., SHARPLEY, AN. and SMITH, VH., 1998. Nonpoint pollution of surface waters with phosphorus and nitrogen. Ecological Applications, vol. 8, no. 3, p. 559-568. http://dx.doi. org/10.1890/1051-0761(1998)008[0559:NPOSWW]2.0.CO;2.

CHAPRA, SC. and DOBSON, HFH., 1981. Quantification of the lake typologies of Naumann (surface quality) and Thienemann (oxygen) with special reference to the Great lakes. Journal of Great Lakes Research, vol. 7, no. 2, p. 182-193. http://dx.doi. org/10.1016/S0380-1330(81)72044-6.

Companhia de Saneamento de Minas Gerais - COPASA. Soluções Integradas de Engenharia - CONCREMAT, 2009. Programa de saneamento ambental para a bacia do Ribeirão da mata. Relatório técnico gerencial. Belo Horizonte: COPASA/CONCREMAT. Availabre from: $<$ http://sites.google.com/site/ribeiraodamata/ home/programa-de-saneamento-ambiental-rib-mata $>$ Access in: 10 Aug. 2010.

COUTINHO, ME. and BARBOSA, FAR., 1986. Distribuição vertical de matéria orgânica, nitrogênio orgânico total, fósforo total e algumas formas iônicas dos sedimentos recentes de 3 lagos de Minas Gerias. Acta Limnologica Brasiliensia, vol. 1, p. 401-429.

DODDS, WK. and COLE, JJ., 2007. Expanding the concept of trophic state in aquatic ecosystems: it's not just the autotrophs. Aquatic Sciences, vol. 69, no. 4, p. 427-439. http://dx.doi. org/10.1007/s00027-007-0922-1.

ESTEVES, FA., 1988. Considerações sobre a aplicação da tipologia de lagos temperados a lagos tropicais. Acta Limnologica Brasiliensia, vol. 2, p. 3-28. 
FRATERRIGO, JM. and DOWNING, JA., 2008. The influence of land use on lake nutrients varies with watershed transport capacity. Ecosystems, vol. 11, no. 7, p. 1021-1034. http://dx.doi. org/10.1007/s10021-008-9176-6.

GOLTERMAN, HL., CLYMO, RS. and OHMSTAD, MAM., 1978. Methods for chemical analysis of freshwaters. 2nd ed. Oxford: Blackwell Scientific Publications. 213 p.

GOONETILLEKE, A., THOMAS, E., GINN, S. and GILBERT, D., 2005. Understanding the role of land use in urban stormwater quality management. Journal of Environmental Management, vol. 74, no. 1, p. 31-42. http://dx.doi.org/10.1016/j.jenvman.2004.08.006. PMid:15572079.

HAMILTON, PB., GAJEWSKI, K., ATKINSON, DE. and LEAN, DRS., 2001. Physical and chemical limnology of 204 lakes from the Canadian Arctic Archipelago. Hydrobiologia, vol. 457, no. 1-3, p. 133-148. http://dx.doi.org/10.1023/A:1012275316543.

HIETEL, E., WALDHARDT, R. and OTTE, A., 2004. Analysing land-cover changes in relation to environmental variables in Hesse, Germany. Landscape Ecology, vol. 19, no. 5, p. 473-489. http:// dx.doi.org/10.1023/B:LAND.0000036138.82213.80.

Instituto Brasileiro de Geografia e Estatística - IBGE, Sistema IBGE de Recuperação Automática-SIDRA. 2010. Censo Demográfico e Contagem da População:Tabela 3107. Available from: <http://www. sidra.ibge.gov.br/bda/tabela/listabl.asp? $\mathrm{z}=\mathrm{cd} \& \mathrm{o}=5 \& \mathrm{i}=\mathrm{P} \& \mathrm{c}=3107>$. Access in: 20 Oct. 2011.

Instituto Mineiro de Agropecuária - IMA, 2011. Serviço - Fale conosco - Consulta ao banco de dados. Available from: $<$ http:// www.ima.mg.gov.br/> Access in: 01 Nov. 2011.

KITAKA, N., HARPER, DM. and MAVUTI, KM., 2002. Phosphorus inputs to Lake Naivasha, Kenya, from its catchment and the trophic state of the lake. Hydrobiologia, vol. 488, no. 1-3, p. 73-80. http://dx.doi.org/10.1023/A:1023362027279.

KNOLL, LB., VANNI, MJ. and RENWICK, WH., 2003. Phytoplankton primary production and photosynthetic parameters in reservatoirs along a gradient of watershed land use. Limnology and Oceanography, vol. 48, no. 2, p. 608-617. http://dx.doi. org/10.4319/lo.2003.48.2.0608.

KOROLEFF, F., 1976. Determination of ammonia. In GRASSHOFF, K. (Ed.). Methods of seawater analysis. Weinheim: Verlag Chemie. p. 126-133.

LAMPARELLI, MC., 2004. Grau de trofia em corpos d'água do estado de São Paulo: avaliação dos métodos de monitoramento. São Paulo: Universidade de São Paulo. 238 p. Doctoral thesis in Science.

LIU, W., ZHANG, Q. and LIU, G., 2010. Lake eutrophication associated with geographic location, lake morphology and climate in China. Hydrobiologia, vol. 644, no. 1, p. 289-299. http://dx.doi. org/10.1007/s10750-010-0151-9.

LORENZEN, CJ., 1967. Determination of chlorophyll and pheo-pigments: spectrofotometric equations. Limnology and Oceanography, vol. 12, no. 2, p. 343-346. http://dx.doi.org/10.4319/ lo.1967.12.2.0343.

MACKERET, FJH., HERON, JF. and TALLING, JF., 1978. Water analysis: some revised methods for limnologists. Kendall: Titus Wilson \& Son. 117 p. Freshwater Biological Association Scientific Publication, no. 39.

MERCANTE, CTJ. and TUCCI-MOURA, A., 1999. Comparação entre os índices de Carlson e de Carlson modificado aplicado a dois ambientes aquáticos subtropicais. Acta Limnologica Brasiliensia, vol. 11, no. 1, p. 1-14.
NÕGES, P., NÕGES, T., TUVIKENE, L., SMAL, H., LIGEZA, S., KORNIJÓW, R., PECZULA, W., BÉCARES, E., GARCIACRIADO, F., ALVAREZ-CARRERA, C., FRENANDEZ-ALAEZ, C., FERRIOL, C., MIRACLE, RM., VICENTE, E., ROMO, S., VAN DONK, E., VAN DE BUND, W., JENSEN, JP., GROSS, EM., HANSSON, L-A., GYLLSTRÖM, M., NYKÄNEN, M., DE EYTO, E., IRVINE, K., STEPHEN, D., COLLINGS, S. and MOSS, B., 2003. Factors controlling hydrochemical and trophic state variables in 86 shallow lakes in Europe. Hydrobiologia, vol. 506-509, no. 1-3, p. 51-58. http://dx.doi.org/10.1023/ B:HYDR.0000008541.36537.51.

NÕGES, T., 2009. Relationships between morphometry, geographic location and water quality parameters of European lakes. Hydrobiologia, vol. 633, no. 1, p. 33-43. http://dx.doi. org/10.1007/s10750-009-9874-x.

Organization for Economic Co-Operation and Development OECD, 1982. Eutrofication of waters: monitoring, assessment and control. Paris: OECD. 154 p.

PATRUS, MLRA., 1998. Relatórios temáticos do Zoneamento da APA Carste de Lagoa Santa - estudos hidrológicos e qualidade das águas de superficie. Belo Horizonte: IBAMA/CPRM. 58 p.

SALAS, HJ. and MARTINO, P., 1991. A simplified phosphorus trophic state model for warm-water tropical lakes. Water Research, vol. 25, no. 3, p. 341-350. http://dx.doi.org/10.1016/00431354(91)90015-I.

Organización Panamericana de la Salud - OPS. Oficina Regional de la Organización Mundial de la Salud - OMS, 2001. Metodologías simplificadas para evaluación de eutroficacion en lagos cálidos tropicales. Relatório CEPIS, 2001. Lima: OPS/CEPIS. 60 p.

SAND-JENSEN, K. and STAEHR, PA., 2007. Scaling of pelagic metabolism to size, trophy and forest cover in small Danish lakes. Ecosystems, vol. 10, no. 1, p. 128-141. http://dx.doi.org/10.1007/ s10021-006-9001-z.

SCHINDLER, DW., 2012. The dilemma of controlling cultural eutrophication of lakes. Proceedings. Biological Sciences, vol. 279, no. 1746, p. 4322-4333. http://dx.doi.org/10.1098/rspb.2012.1032. PMid:22915669.

SHEELA, AM., LETHA, J. and JOSEPH, S., 2011. Environmental status of a tropical lake system. Environmental Monitoring and Assessment, vol. 180, no. 1-4, p. 427-449. http://dx.doi.org/10.1007/ s10661-010-1797-5. PMid:21127964.

TARANU, ZE. and GREGORY-EAVES, I., 2008. Quantifying relationships among phosphorous, agricuture, and lake depth at na inter-regional scale. Ecosystems, vol. 11, no. 5, p. 715-725. http://dx.doi.org/10.1007/s10021-008-9153-0.

TOLEDO, AP., TALARICO, M., CHINEZ, SJ. and AGUDO, EG., 1983. Aplicação de modelos simplificados para a avaliação de processo da eutrofização de lagos e reservatórios tropicais. In Congresso Brasileiro de Engenharia Sanitária, 1983. Camburiú. Camburiú: UFSC. p. 1-34.

VANNI, MJ., RENWICK, WH., BOWLING, AM., HORGAN, MJ. and CHRISTIAN, D., 2011. Nutrient stoichiometry of linked catchment-lake systems along a gradient of land use. Freshwater Biology, vol. 56, no. 5, p. 791-811. http://dx.doi.org/10.1111/j.13652427.2010.02436.x.

VOLLENWEIDER, RA., 1968. Water management research. Scientific fundamentals of eutrophication of lakes and flowing water, with paticular reference to nitrogen and phosphorous as factors in eutrophication. Paris: OECD. 192 p.

WETZEL, RG., 2001. Limnology. Lake and river ecosystems. 3rd ed. San Diego: Academic Press. 1006 p. 